УДК: 371.321

\title{
БАЛАНС МЕЖДУ ТРАДИЦИЯМИ И ИННОВАЦИЯМИ В ИЗУЧЕНИИ РОМАНА «ПРЕСТУПЛЕНИЕ И НАКАЗАНИЕ» Ф.М. ДОСТОЕВСКОГО
}

\section{Павлова Саргылана Валерьевна} студент БА-ПО-РЯЛ-17 Бурцева Светлана Семеновна к.п.н., доцент ФГАОУ ВО «Северо-Восточный федеральный университет имени М.К. Аммосова»

Аннотация: В статье представлен пример поиска и приемлимости баланса между традициями и инновациями в методике преподавания литературы в школе. Рассматриваются некоторые проблемы взаимодействия традиционного и инновационного подходов при изучении романа «Преступление и наказание» Ф.М. Достоевского.

Ключевые слова: литературоведческий анализ романа, интерпретация художественного текста, учебно-методические комплексы, сервисы визуализации

\section{THE BALANCE BETWEEN TRADITIONS AND INNOVATIONS IN THE STUDY OF THE NOVEL «CRIME AND PUNISHMENT» BY F.M. DOSTOEVSKY}

\section{Pavlova Sargylana Valeryevna Burtseva Svetlana Semyonovna}

\begin{abstract}
The article presents an example of the search for and acceptability of a balance between traditions and innovations in the methodology of teaching literature at school. Some problems of interaction of traditional and innovative approaches in the study of the novel "Crime and Punishment" by F. M. Dostoevsky are considered.
\end{abstract}

Key words: literary analysis of the novel, interpretation of the literary text, educational and methodological complexes, visualization services

Начало XXI века было ознаменовано зарождением новой эпохи 
развития цивилизации - шестого технологического уклада, который и по сей день сопровождается целым рядом инноваций во всех сферах жизнедеятельности человека. Мир меняется и преобразовывается, и не только в плане техники, технологий и производства, но и менталитета, сознания, морали, психики и даже физиологии. С каждой волной убыстряются скорости и темпы динамического хода этих явлений, порой создавая множество противоречий и проблем. Всего примерно за два - три десятилетия в нашей стране произошли такие перемены локального и глобального масштаба, что общество едва успевает «переваривать» процессы и их результаты. Большие перемены коснулись и сферы образования. Необходимо отметить, что мы продолжаем переживать результаты модернизации российского образования, связанные с переходом в реалии Болонского процесса, продолжающейся оптимизации в нем из-за глобального финансового кризиса, плавно переходя в перспективы всемирного дистанционного обучения. Время «великих переходов и скачков» всегда сопровождается критикой и отвержением прошлого, «старого», уходящего, причисленных к «пережиткам», почти повальным увлечением «новым» - «инновационным», заманчивым своей перспективой в будущем, актуальностью сегодня. Но должен быть объективный и адекватный подход ко всему «старому» и «новому», тем более, когда это касается сферы образования, то есть судьбы человека, общества и государства.

Еще в начале нового века (особенно в 2005-2007 годах) шли весьма содержательные дискуссии о плюсах и минусах «народного образования» советского исторического периода. Действительно, советская система образования имеет достаточно разноречивые оценки качества и широкий спектр результатов. При этом стоит только заметить, что будущим учителям полезнее будет придерживаться фундаментальных подходов к своей профессиональной подготовке. Например, в традиционной методике преподавания русской литературы в школе и сегодня можно опереться на весьма важные научные знания и практические примеры применения эффективных, результативных приемов, методов, технологий обучения русской классике.

Обратимся к изучению романа «Преступление и наказание» Федора Михайловича Достоевского - к одному из самых сложных и противоречивых романов XIX века. Роман христианского пророка, определяемый как социально-психологический и социально-философский, является основным программным произведением школьного литературного образования, и давно 
разработан отечественными методистами для изучения в старших классах, но до сих пор вызывает затруднения как у обучающихся, так и у обучающих.

Трудностями изучения данного произведения в школе можно считать:

- $\quad$ художественный текст содержит выражение глубокой религиозной христианской философии автора, которая вызывает трудности восприятия и понимания у читателей, отдаленных от него и по времени, и по менталитету, а также из-за особенностей возраста и недостаточности их жизненного опыта;

- содержание романа отличается сложной проблематикой, многослойным конфликтом, что представляют значительные трудности у мало подготовленного читателя;

- форма романа осложнена многотипной системой образов, герои которых трактуются иногда весьма противоречиво и неоднозначно;

- авторская идея романа отражает особенности эпохи создания произведения, культурные коды русского человека - православного христианина и национального типа мировосприятия, мировоззрения;

- неподготовленному читателю трудно выходить из рамок своего понимания к общечеловеческому, высоконравственному согласию между человеком и обществом, личностью и миром;

- в силу выше перечисленных трудностей и сложностей возможно одностороннее толкование романа.

В отечественной методике преподавания существуют множество подходов к изучению романа «Преступление и наказание», с успехом апробированные и те, которые не всегда оказываются эффективными. Несомненно, современный урок должен проходить не только в форматах традиционного обучения, но также и в свете инновационного обучения с применением современных информационно-коммуникационных, компьютерных и сетевых технологий.

Мы придерживаемся пути поисков определенного баланса между традиционным и инновационным методиками обучения - эффективного комбинированного подхода к изучению романа «Преступление и наказание» Ф.М. Достоевского, сочетающего лучшие опыты традиционного и апробации инновационного. Для этого требуется достаточное знание теоретических основ традиционной методики преподавания русской литературы по трем аспектам (психологи-педагогического, литературоведческого и методического), систематизированное в соответствии с новыми требованиями и реалиями. 
Процесс обучения и воспитания на уроках изучения романа «Преступление и наказание» не может быть результативным и эффективным, если учитель-словесник не будет опираться на литературоведческие исследования о жизни и творчестве Ф.М. Достоевского, среди которых, несомненно, должны быть труды М.М. Бахтина, С.В. Белова, А.М. Буланова, Ю.Ф. Карякина, Р.Г. Назирова, Н.М. Чиркова и других. Философскую, религиозную христианскую основу романа сложно будет трактовать, не обращаясь к В. Соловьеву, Л. Шестову, Н. Бердяеву. Неоценимую ясность в данном аспекте могут внести И.А. Есаулов, В.Н. Захаров, В.А. Котельников, Ф.Б. Тарасов, Е.А. Трофимов и другие.

Как важное достижение отечественной методики преподавания русской литературы можно отметить развитие теории школьного литературоведческого анализа художественного текста (начиная с трудов основоположников - Ф.И. Буслаева, В.И. Водовозова, В.Я. Стоюнина, В.П. Острогорского). Так были описаны методы школьного литературоведческого анализа художественного текста «вслед за автором» М.А. Рыбниковой, В.В. Голубковым， М.Д. Сосницкой， В.А. Никольским и другими. Еще в самом начале этих разработок М.А. Рыбникова ввела способ анализа как «естественный метод работы над произведением» литературы. Особая заслуга принадлежит Т.Г.Браже за описание общих принципов методики целостного изучения многопланового прозаического произведения. Он предлагал методику изучения художественного текста в школе «вслед за автором» с построением в соответствии с ней системы уроков. В свою очередь Д.К. Мотольская, Н.А. Соснина, Ю.И. Лыссый, Б.А. Есин внесли композиционный анализ художественного текста.

Используя такие базовые теоретические знания, возможно построить усовершенствованную систему уроков целостного изучения романа «Преступление и наказание». При этом композиционный анализ произведения может стать основой целостного осмысления художественной идеи произведения, приближения к пониманию авторской идеи. Композиционный анализ текста представляется удобным для закономерных переходов к контексту романа, к его системе образов, художественным деталям, эпизодам, речевой характеристике персонажей. Для школьного изучения сложности встречаются при понимании композиционной роли образа Петербурга, снов Раскольникова, его динамики нравственного и духовного роста. Но главным остается эстетическое восприятие целостности художественного текста. Важно соблюдать рамки адекватной интерпретации, сохранять смысл поиска 
авторской идеи, говорить не о герое, а с героем. Важный момент при этом, понимание того, что Достоевскому удалось передать всю противоречивость и неопределенность в мотивах преступления Раскольникова, что дает возможность читателю осознавать сложность и переплетения социальных проблем, полифонию внутренней свободы человека, природы и истоков безнравственности, несправедливости, бунта, революции во всем.

Несомненно, отдельную трудность сегодня представляет и религиозная основа романа. В этом плане без обращения к идеям Владимира Соловьева, письмам самого автора вряд ли придется обойтись. Это наиболее актуальные идеи о религиозном идеале, «внутреннем грехе гордости», «самобоготворении», «сознании своей греховности» и «веры в Бога». И этот роман тем и интересен, что затрагивает такие глубокие уголки души человека, без открытия которых не может состояться его внутренний мир, обретение себя и мира.

Если в пределах школьного литературного образования все это достичь не удастся, то хотя бы должно состояться первое общение с романом с последующим возвращением к нему. Это важно и по причине того, что сегодня уровень и качество читательской культуры российского общества, к сожалению, утеряли былые строки рейтингов. Россия больше не «самая читающая страна в мире». Но надежда на сохранение хотя бы некоторых традиций литературоцентризма еще тлеет. Во-первых, что постепенное снижение интереса к литературе как к виду искусства отмечается не только в России. Проблема литературного чтения носит глобальный характер. Причину этого можно объяснить реалиями современной эпохи, когда чтение не выдерживает конкуренции с иными источниками получения информации и проведения досуга. Во-вторых, феномен русской сетературы, сохранение в эпоху Интернета тягу к словотворчеству, художественному тексту, наличие читателя сетевой литературы кое-что «обещает впереди».

Опора на традиции отечественной методики преподавания русской литературы ощущается и в действующих учебно-методических комплексах (УМК) (Коровиной В.Я., Полухиной В.П., Журавлева В.П., Збарского И.С. и других, Чертова В.Ф., Трубиной Л.А., Ипполитовой Н.А. и других, Лебедева Ю.В., Михайлова О.Н., Шайтанова И.О., Чалмаева В.А. и других, Сахарова В.И., Зинина С.А. и других). Переработку методического наследия между тем начинали сами корифеи этой области науки. Так, например, в конце 90-ых программа литературы под редакцией Т.Ф. Курдюмовой ввела для школьного изучения произведения русского зарубежья и «возвращенную 
литературу». Переход на концентрическую логику изучения литературы поддержали тогда и коллективы разработчиков под редакцией В.Я. Коровиной, Г.И. Беленького. Относительно основательно разработанных современных УМК, имеющих по требованиям времени все элементы и составляющие части от тетрадей до «методичек» для поддержки учителяпрактика, можно сказать только, что они чрезмерной методической опекой не оставили места ни поиску, ни творчеству, ни ученикам, ни учителям. Остается строго следовать указаниям и рекомендациям, выполнять и отчитываться. А педагогическая практика прошлых лет, прочно подкрепленная теориями отечественной методики преподавания, представляется нам насыщенной новаторскими открытиями, творчеством и мастерством величайших педагогов и учителей изящной словесности. Это и уроки нравственности Е.Н. Ильина, и просветительство Я.А. Фельдштейна, и ответственность перед обществом А.В. Белиной, и многих других.

В целом, можно сделать вывод, что научные традиции оснащают нас богатым систематизированным теоретическим знанием, без которого невозможно создать новое, нельзя овладеть широким видением, глубоким пониманием, то есть фундаментальным подходом к знанию, обучению и воспитанию, образованию, жизни в целом. Особо важным представляется это в аспекте профессиональной подготовки учителей.

Инновационная педагогическая практика сегодня трактуется как альтернатива традиционному обучению и, благодаря новым информационнокоммуникационным технологиям, быстрыми темпами транслируется в широкое образовательное пространство. Природа инновации диктует некоторые ее признаки и характерные черты. Если традиционная методика разрабатывается, оттачивается в основном научно-методической школой, коллективом, проходит стадии эксперимента, апробации, обмена практическими опытами участников, то инновационная педагогическая практика строится на основании одной авторской идеи. Доктор педагогических наук И.М. Осмоловская об этом пишет так: «Инновационные практики имеют локальное распространение, они не институционализированны, не нормируются законами и ведомственными подзаконными актами, не являются обязательными для реализации участниками образовательного процесса. Инновационная образовательная практика обязательно включает новую идею или совокупность идей, развиваемых автором или коллективом авторов». [1, 121-122 с.]. 
Сегодня наиболее актуальными инновационными педагогическими практиками признаны смешанное обучение, «перевернутый класс», гибридное обучение. Многие инновационные методы и приемы обучения связаны с организацией и проведением онлайн-уроков, применением онлайн-платформ, созданием онлайн-курсов в них, овладением сервисами создания образовательного контента и т.д. И все они направлены на практическое решение какой-либо конкретной проблемы, достижения прагматической цели и выполнения объективных задач. На данном этапе инновационного развития российской системы образования всего инновационного достаточно много, и все это находится на стадии заявления, презентации, «проб и ошибок», их анализа и классификации, изучения и осмысления. Характерный лейтмотив данного этапа - отрицание прошлого наследия как явления пережитков и отсталого. При этом весьма часто под названием чего-то «нового» преподносится хорошо известное «старое». Например, некоторые предлагаемые модели проектной деятельности, интерактивных методов давно существуют под другими названиями в традиционной системе обучения. На уроках литературы это: уроки-экскурсии, уроки-дискуссии, конкурсы, концерты, инсценировки, мини-спектакли, литературно-музыкальные композиции, интегрированные уроки, уроки выразительного чтения и т.д. Хотя, конечно, есть и решения комплексного плана. Например, презентация нового российского информационно-коммуникационного сервиса «Сферум» для отечественной системы образования, которая призвана заменить импортный продукт Zoom. Но это скорее и больше техническое решение. А вот с содержательной части процесс несколько начинает затягиваться. Видимо, должна уже наступить следующая стадия развития - стадия перехода от отрицания к поиску истоков, главных кодов, истинных ценностей, соизмерения их результатов, грамотного соотношения с традициями, построения баланса с ними, решения проблем взаимодействия традиционного и инновационного подходов в обучении.

Если традиционные методы обучения преподносят большие систематизированные объемы фундаментального знания, то не стоит их делить на разрозненные фрагменты или органичиваться, например, усвоением краткого содержания романа вместо его целостного изучения, что встречается в реалиях нового литературного образования. Или вместо сочинения по литературе, в котором выпускник должен выразить вариант своей адекватной интерпретации художественного текста, предлагается написать развернутый ответ на вопрос. 
Для наиболее эффективной подачи литературного учебного материала, сжатия их объемов сегодня присутствует целый арсенал компьютерных и сетевых технологий. При переносе традиционных методов и методик на инновационные форматы потребуются решения визуализации информации. Хорошо продуманная, последовательно и логично оформленная инфографика по изучению романа «Преступление и наказание» сделает урок литературы интереснее, увлекательнее, усилит его мотивационную и коммуникативную базу. Инфографика - это способ представления сложной информации в графическом виде, позволяющем точно и лаконично донести свои идеи и мысли до адресата. С помощью инфографики можно эффективно преподнести большой объем материала, наглядно его представить, сопоставив факты и явления во времени и пространстве. Такая подача информации обладает несомненным преимуществом за счет яркой визуализации, простоты и ясности представленного материала, а также большим эмоциональным зарядом и эстетической привлекательностью, что позволит активизировать внимание учащихся на уроке, вовлечь их к обучению, а следовательно, успешнее усвоить учебную программу. Сервисы для создания инфографики позволяют сделать мультимедийные презентации динамичнее, функциональнее. Существуют различные сервисы для создания инфографики (например, Canva, Infogram, Venngage, Easel.ly, Piktochart, Snappa, Prezi и другие). Большинство их предлагают пользователю обширный внутренний интерфейс и большое количество готовых шаблонов, возможности масштабирования (приближения или удаления созданных объектов), построения маршрута по изложению учебного материала, истории, любой темы. Правильный фон, визуальный контекст инфографики проведет читателя и ученика путем открытий и позитивных эмоций.

Таким образом, в изучении романа «Преступление и наказание» Достоевского мы придерживаемся эффективного комбинированного подхода как определенного баланса между традиционным и инновационным методиками обучения русской классике, у которой огромный аксиологический запас воспитания внутреннего мира человека, его нравственных качеств и духовных ценностей. Для современного читателя и учителя это произведение особенное, сложное, наполненное противоречиями и загадками. Достоевскому удалось вложить в созданный им художественный текст, не просто повествование, а сокровенные переживания человека, общества, православия и русского национального характера, а также то общечеловеческое и вечное, что объединяет всех и всегда, во все времена. 
Через этот роман постигается суть добра и зла, человеческих ошибок и грехов, социальных и революционных теорий, значение поиска самого себя и своей веры, любви и счастья. Чтение и изучение его важно для реализации цели и задач литературного образования. А все это требует и усвоения фундаментальных знаний, и применения лучших результатов инновационных практик в комплексе.

\section{Список литературы}

1. Осмоловская И.М. Инновационные образовательные практики в образовательном пространстве школы // Отечественная и зарубежная педагогика. - 2018. Т.1, № 3 (50). С. 120-131. - 121-122 с. URL: https://cyberleninka.ru/article/n/innovatsionnye-obrazovatelnye-praktiki-vobrazovatelnom-prostranstve-shkoly 